\title{
Germination, growth and morpho-anatomical development of Catasetum macrocarpum (Orchidaceae) in vitro
}

Germinação, crescimento e desenvolvimento morfoanatômico de Catasetum macrocarpum (Orchidaceae) in vitro

\author{
Wagner de Melo Ferreira ${ }^{1,3}$, Sidney Pereira de Oliveira ${ }^{1}$, Rogério Mamoru Suzuki ${ }^{2}$, \\ Kellen Lagares Ferreira Silva ${ }^{1} \&$ Jack Wild Pereira Soares Júnior ${ }^{1}$
}

\begin{abstract}
Catasetum macrocarpum is an epiphytic orchid that has been subjected to strong environmental pressure in the state of Tocantins. This investigation aimed at studying the germination, growth and morpho-anatomical development of $C$. macrocarpum under in vitro conditions. The effects of three culture media on the in vitro germination and on the multiplication and growth of 90-day-old seedlings were studied: Murashige \& Skoog (full- and halfstrength), Knudson C, and Vacin \& Went. The effects of different concentrations of benzyladenine (BA) and naphthaleneacetic acid (NAA) on the multiplication and growth of 120-day-old plants were evaluated. Anatomical studies were conducted on protocorms at different developmental stages. Acclimatization was also carried out. Knudson $\mathrm{C}$ was the best medium for seed germination whereas Vacin \& Went promoted the greatest protocorm development. Half-strength Murashige \& Skoog was the most effective medium for seedling multiplication and growth. The results revealed that $1 \mathrm{mg} \mathrm{L}^{-1} \mathrm{BA}$ was the best treatment for shoot proliferation and leaf production. NAA at $0.5 \mathrm{mg} \mathrm{L}^{-1}$ strongly favored root formation. The anatomical study revealed that the early stages of $C$. macrocarpum development do not always coincide with the morphological phases described. The acclimatization of C. macrocarpum plants provided successful results regarding plant survival.
\end{abstract}

Key words: acclimatization, culture media, growth regulators, histological study, orchid.

Resumo

Catasetum macrocarpum é uma orquídea epifitica que está sob forte pressão ambiental no estado do Tocantins. Este trabalho teve como objetivo estudar a germinação, crescimento e desenvolvimento anatômico de C. macrocarpum sob condições in vitro. Foram estudados os efeitos de três meios de cultura na germinação e na multiplicação e crescimento de plântulas: Murashige \& Skoog (MS e 1/2MS), Knudson C, and Vacin \& Went (VW). Avaliaram-se os efeitos de diferentes concentrações de benziladenina (BA) e ácido naftalenoacético (ANA) na multiplicação e crescimento de plantas com 120 dias de idade. Estudos anatômicos foram conduzidos em protocormos em diferentes estágios de desenvolvimento. A aclimatização também foi realizada. Knudson C foi o melhor meio para a germinação enquanto que o VW promoveu o melhor desenvolvimento dos protocormos. O meio $1 / 2 \mathrm{MS}$ foi o mais eficaz para a multiplicação e crescimento das plântulas. BA na concentração de $1 \mathrm{mg} \mathrm{L}^{-1}$ foi o melhor tratamento para a formação de brotos e folhas. ANA na concentração de $0,5 \mathrm{mg} \mathrm{L}^{-1}$ favoreceu fortemente o enraizamento. Os estudos anatômicos revelaram que os estágios iniciais do desenvolvimento de C. macrocarpum nem sempre coincidem com as fases morfológicas descritas. A aclimatização das plantas foi eficaz em relação à porcentagem de sobrevivência.

Palavras-chave: aclimatização, estudo histológico, meios de cultura, orquídea, reguladores de crescimento.

\section{Introduction}

Several techniques and methodologies have long been used for the propagation and cultivation of orchids, not only to increase germination percentages but also to achieve optimal initial development of the seedlings obtained. After the discovery of in vitro asymbiotic seed germination by Knudson in 1922 and shoot-tip culture by Morel in 1964, the production and commercialization of orchid plants have greatly increased (Hossain et

\footnotetext{
${ }^{1}$ Universidade Federal do Tocantins, Núcleo de Estudos Ambientais, R. 3 s/n, Jardim dos Ipês, C.P. 111, 77500-000, Porto Nacional, TO, Brasil.

${ }^{2}$ Instituto de Botânica, Seção de Orquidário do Estado, Av. Miguel Stefano 3687, 04301-902, São Paulo, SP, Brasil.

${ }^{3}$ Author for correspondence: wmelouft@yahoo.com
} 
al. 2010). Moreover, plant propagation by using in vitro techniques has been regarded as a practical alternative method for the multiplication of rare and endangered species for conservation and utilization (Wochok 1981; Fay 1992), which certainly can be applied to orchids (Ponert et al. 2013). In addition to their ecological and economic importance, the in vitro techniques applied to orchid species are useful for anatomical, physiological, mineral nutrition and phytopathological studies, for cryopreservation, clonal propagation as well as for plant breeding and development of hybrids (Kauth et al. 2006; Engelmann 2011; Panwar et al. 2012).

Among the most relevant factors associated with the in vitro germination and growth of orchids, those related to the nutritional composition of the culture medium are still not comprehensively understood. The importance of the culture medium, especially its mineral nutrients and hormonal makeup for the formation, growth and multiplication of different organs, has been demonstrated for a large number of plant species including orchids (Figueiredo et al. 2007; Unemoto et al. 2007). A great variety of culture media has been used for the in vitro growth of orchids, however, such variety has not established whether a specific medium is comparatively better than another one or not. Thus, the selection of culture media must be based on the species and on the technical approach to be used (Pasqual et al. 1997). Moreover, according to several authors (Kauth et al. 2006; Suzuki et al. 2009; Suzuki et al. 2010; Suzuki et al. 2012), germination responses to different culture media vary greatly among species. The same can be said of the initial growth of seedlings (Suzuki et al. 2009).

In the northern part of Brazil, particularly in the State of Tocantins, increasing human activities such as agriculture, animal husbandry and flooding caused by the construction of a great number of hydroelectric dams have the potential to seriously endanger several plants species including orchids. In light of that, it is important to emphasize that the in vitro culture of orchids is a valuable tool for the study of these species and can be used as a practical instrument to help prevent them from being included in lists of threatened species as well as to propagate them at a large scale, aiming for their reintroduction in environmentally protected areas or in areas that have previously been subjected to human disturbance. Regarding Cerrado orchid species specifically, which have not been broadly investigated, studies that focus on the understanding of their seed germination and initial development are highly relevant.
Catasetum macrocarpum, the orchid species studied in the present investigation, naturally occurs in woodlands and forests bordering rivers and streams in northern Brazil, and in the state of Tocantins it has been subjected to strong environmental pressure due to the considerable decrease of these areas primarily as a consequence of the construction of several hydroelectric power plants along the Tocantins River and its tributaries as well as because of the extensive illegal collection from wild populations. For these reasons, studies related to seed germination and plant development are of utmost importance to prevent its possible extinction, since they will enable the production of plants for use in conservation programs and for commercial exploitation of the species. In addition, in vitro culture can be an interesting technique for germplasm conservation and future use of the species. In this paper the in vitro germination and initial development of C. macrocarpum as well as a protocol for its acclimatization under shade-house conditions are described. A histological depiction of the initial stages of development is also provided.

\section{Material and Methods}

Plant species and material

Catasetum macrocarpum Rich. ex Kunth, popularly known as "jumping orchid", possesses ovoid to spindle-shaped pseudobulbs which are surrounded by leaf sheaths when young. Leaves are thin, deciduous, pleated and elliptical-lanceolate in shape, with acute or acuminate apices. Its inflorescence is racemose, arched or pendent, originated from the basal pseudobulb nodes. The flowers are fleshy and the column of the male flowers is pointed, erect, with two touch-sensitive filaments at its base, which are responsible for the ejection of the pollinia. The female flowers are green and bear helmet-shaped lips turned toward the top of the flower. The species occurs from Venezuela to southern Bahia, although it is more frequently found in the Amazon region, including the Cerrado (Menezes 2004).

Six mature fruits of Catasetum macrocarpum, prior to dehiscence and collected from six different plants growing in a shade-house at the Environmental Studies Center (Neamb), Federal University of Tocantins, Brazil, were the source of seeds for the present study. Fruits were initially immersed in ethyl alcohol for two minutes. Next, they were surface sterilized with commercial bleach ( $2.5 \%$ active chlorine) for 15 minutes, followed by three 15 -minute rinses in deionized and autoclaved 
water. Subsequently, seeds were removed from the fruits and thoroughly mixed in a sterile beaker. Onefifth of the seed mix was removed and immersed in deionized and autoclaved water for 30 minutes (aqueous suspension of seeds) before inoculation onto the culture medium.

Culture media and growth conditions

The effects of three culture media on in vitro germination were studied: Murashige \& Skoog (1962) used at two different concentrations of its macronutrients (full- and half-strength) [MS; $1 / 2 \mathrm{MS}$ ], Knudson C (1946) [KC], and Vacin \& Went (1949) [VW]. They were all supplemented with $0.4 \mathrm{mg} \mathrm{L}^{-1}$ tiamin, $100 \mathrm{mg} \mathrm{L}^{-1}$ myo-inositol and $2 \%$ sucrose. The $\mathrm{pH}$ of the media was adjusted to $5.85 \pm 0.01$, and $0.2 \%$ Phytagel (Sigma Co., USA) was added to the media before autoclaving at $121^{\circ} \mathrm{C}$ and $105 \mathrm{kPa}$ for $15 \mathrm{~min}$. There were ten replicates for each culture medium. Each replicate consisted of a 100-mL glass jar containing $40 \mathrm{~mL}$ of culture medium onto which $250 \mu \mathrm{L}$ of the aqueous suspension of seeds mentioned above (containing ca. 400 seeds) was inoculated. The cultures were kept in a growth room at $27 \pm 2{ }^{\circ} \mathrm{C}$ under a 16-hour photoperiod provided by cool-white fluorescent lamps (Empalux, Brasil) at 30-35 $\mu \mathrm{mol} \mathrm{m}^{-2} \mathrm{~s}^{-1}$.

\section{Germination and initial growth}

The germination analysis was carried out according to Suzuki et al. (2009). Seeds were considered germinated when swollen embryos (protocorm phase) were visible on the surface of the media. Material from six replications for each treatment were placed on microscope slides (two slides per replication) and analyzed with use of a dissecting microscope. The counts encompassed all protocorms on each slide, which were gridded to help the counting procedure.

Ninety days after the onset of germination, the individuals contained in three replications were evaluated in relation to the stages of protocorm development (morphological characteristics) so that the growth index could be calculated (modified from Spoerl 1948). Four different developmental stages were considered according to Suzuki et al. (2009): stage 1: swollen green embryos (protocorm phase); stage 2: protocorm bearing one leaf; stage 3: protocorm bearing two or more leaves; stage 4: seedling with leaves and roots. The percentages of individuals obtained for each developmental stage and for each replication were multiplied by 1, 2, 3 and 4 (weights) according to their respective stages.
The growth index of each replication was the sum of all stages of their individuals. Five microscope slides per replication containing protocorms/ seedlings were prepared and analyzed by means of a dissecting microscope.

\section{Effects of culture media}

and growth regulators

on multiplication and growth

The influence of the culture media listed above on the multiplication and growth of seedlings was also studied. After selecting the most suitable medium for seedling growth, the effects of different concentrations of benzyladenine [BA] and naphthaleneacetic acid [NAA] (in combinations of $0,0.5$ and $1 \mathrm{mg} \mathrm{L}^{-1}$ ) on plant multiplication and growth were also evaluated. One hundred twentyday-old seedlings of $1.0 \pm 0.3 \mathrm{~cm}$ in length, which had all roots removed, were used as explants in the experiments. There were five replicates for each treatment. Each replicate consisted of 200-mL glass jars with plastic covers containing six explants $(n=30)$. The experimental conditions were the same as described for the germination experiment. The results were analyzed according with the following growth parameters: number of shoots and roots produced per inoculated explant, length of the longest shoot (measured from the base of the plant to the apex of the longest leaf) and root as well as dry mass of shoots and roots after 120 days of culture.

\section{Anatomical studies}

Plant material for the anatomical studies was collected from KC medium 90 days after the onset of germination. Samples of each developmental stage were fixed according to Johansen (1940) in $50 \%$ FAA (formaldehyde, acetic acid and ethyl alcohol) kept under vacuum for 24 hours and stored in $70 \%$ alcohol, according to Jensen (1962) for paraffin embedding and subsequent dehydration in ethyl and butyl series. Samples were immersed in paraffin $+8 \%$ beeswax, following different cutting plane orientations (transverse and longitudinal), and placed on a wooden support.

Longitudinal and transverse sections (10 $\mu \mathrm{m}$ thick) were made in a manual, semi-motorized rotary microtome (Leica RM2245, Nussloch, Germany) and attached to the slide using Haupt adhesive. Following this, the sections were deparaffinized in a xylolic series, hydrated in an ethyl series and stained in $1 \%$ safranin and astra blue for $20 \mathrm{~min}$ then subsequently subjected to dehydration in ethyl, butylic and xylolic series and 
mounted in series between slide and coverslip using Canada balsam. Observations and recordings were performed under a Leica DM500 optical microscope (Wetzlar, Germany), with a Leica ICC50HD digital camera (Wetzlar, Germany) attached to it.

\section{Acclimatization}

Sixty 12-month-old plants of C. macrocarpum, varying from 2 to $3 \mathrm{~cm}$ in length, were removed from the culture vessels, rinsed in running water and transferred to transparent rectangular plastic containers with covers $(10 \mathrm{~cm}$ height $\times 19 \mathrm{~cm}$ width $\times 29$ length) containing Bioplant Prata (Bioplant Agrícola Ltda, Minas Gerais, Brazil) and sphagnum $(1: 0,1: 1$ and $2: 1, \mathrm{v} / \mathrm{v})$ as the potting mixture, and kept under the same environmental conditions as described for seed germination (growth room). Plants were sprayed with $250 \mathrm{~mL}$ of water once a day for 30 days. Following that, the containers were half-opened and the spray regime was maintained as before for the next 30 days (first acclimatization phase). After that, plants were transferred to individual round plastic pots (7 $\mathrm{cm}$ height $\times 6 \mathrm{~cm}$ basal diameter, perforated at the base) containing a mixture of Ouro Negro substrate (Ouro Negro Ltda., Goiás, Brazil) and Bioplant Prata substrate $(2: 1, \mathrm{v} / \mathrm{v})$, and were daily sprayed with an adequate amount of water to keep the mixture humid (second acclimatization phase). The pots were kept in the same growth room described previously. Sixty days later, plants were transferred to a shade-house with $75 \%$ retention of solar radiation flux and were watered daily (third acclimatization phase). The experiment consisted of three replicates per treatment and the results were evaluated as percentage plant survival 60 days after the end of each phase.

\section{Experimental design}

and statistical analysis

A completely randomized experimental design was used in this study. Analysis of variance (ANOVA) was used to evaluate germination and the growth parameters, and the means were compared by the Tukey test at the $5 \%$ probability level. Percentage results were arcsine transformed to normalize variation. The experiments were repeated twice.

\section{Results and Discussion}

Germination and initial growth

The first evidence of the germination of Catasetum macrocarpum seeds was detected 15 days after seed inoculation, which could be recognized by the presence of green protocorms on the surface of the culture media. Several studies have confirmed that the time required for the germination of orchid seeds after inoculation onto the culture medium varies greatly among species. Hadrolaelia tenebrosa germinated 20 days after inoculation (Suzuki et al. 2009). Suzuki et al. (2010) verified that Cattleya bicolor seeds germinated ca. 15 days after in vitro inoculation. Seeds of Comparettia falcata germinated ca. 40 days following in vitro inoculation (Manrique et al. 2005) and seeds of Cattleya forbesii germinated 30 days following in vitro inoculation (Schneiders et al. 2012).

Catasetum macrocarpum seeds germinated on all culture media assessed and significant statistical differences $(P<0.05)$ were not detected among them (Fig. 1a). However, the highest germination percentage was obtained on KC. Calopogon tuberosus seeds also germinated better on $\mathrm{KC}$
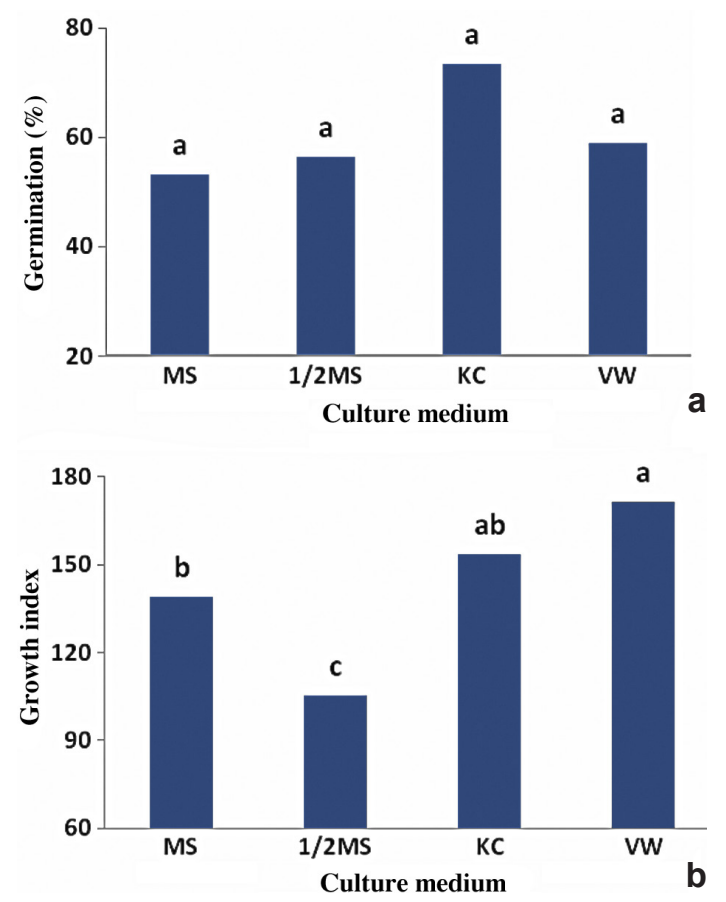

Figure 1 - a. Germination percentages of Catasetum macrocarpum seeds on Murashige and Skoog (MS and $1 \frac{1}{2} \mathrm{MS}$ ), Knudson (KC), and Vacin and Went (VW) media; b. growth index of Catasetum macrocarpum on Murashige and Skoog (MS and 1/2MS), Knudson (KC), and Vacin and Went (VW) media, 90 days after the onset of germination. Bars headed by the same letter are not significantly different according to the Tukey's test at the $5 \%$ probability level. 
(Kauth et al. 2006). In addition, Suzuki et al. (2009) also reported that $\mathrm{KC}$ provided the best germination response in Hadrolaelia tenebrosa. According to Stewart (1989), orchids can be divided into two major groups depending on their basic nutritional requirements for in vitro germination. The first group encompasses species whose seeds germinate on media with low nutrient concentrations such as Knudson (1946) and Vacin \& Went (1949). The second group includes species that require media with higher amounts of macronutrients as for example Murashige \& Skoog (1962). As $C$. macrocarpum is epiphytic and naturally occurs in nutrient-poor environments, it exhibited better germination responses when sown on a medium of low nutrient composition and thus falls into the first group proposed by Stewart (1989).

The results obtained could also be related to the low nitrogen levels in KC, since Arditti (1967) stated that low concentrations of that nutrient stimulate germination whereas high concentrations are inhibitory for most orchid species. Indeed, of the culture media investigated in the present study, those with the highest nitrogen levels (MS and $1 / 2 \mathrm{MS}$ ) were the ones that provided the lowest germination percentages. Similar results were obtained in Nothodoritis zhejiangensis by Zeng et al. (2011) using the same media assessed in the present study, although in that study, KC provided a significantly higher germination percentage than VW, MS and $1 / 2 \mathrm{MS}$.

Another aspect that might have influenced the germination of Catasetum macrocarpum seeds is the relative amounts of ammonium and nitrate in the medium. They germinated better in a medium supplemented with a balanced ratio of those two nitrogen sources, which is the case of $\mathrm{KC}$. When the proportion of nitrate is higher (MS and $1 / 2 \mathrm{MS}$ ) germination percentage decreased although this result was not statistically significant. This is probably due to the fact that protocorms are not able to assimilate nitrogen from a nitrate source since nitrate reductase is not active at this developmental stage as was stated by Raghavan and Torrey (1964) for a Cattleya hybrid. Kauth et al. (2006) reported that media with higher concentrations of ammonium nitrogen provided better germination responses in Calopogon tuberosus. Similar results were reported for Dendrobium hookerianum (Paul et al. 2012) and for Ansellia africana (Vasudevan \& Van Staden 2010). The results observed in $C$. macrocarpum corroborate the findings of those authors considering that the second best medium for germination (VW) has a higher ammonium: nitrate ratio.

During germination, the embryos of orchids develop into protocorms, which later differentiate into shoots and roots, thus creating a seedling (Kraus et al. 2006). Based on the formation of these structures it is possible to evaluate seedling development after germination by means of the growth index. Figure $1 \mathrm{~b}$ displays the results obtained for the growth index on the culture media assessed 90 days after the onset of germination. Figure 2 shows the four developmental stages used to analyze protocorm development of Catasetum macrocarpum from seed germination in vitro (as previously described).

$\mathrm{VW}$ and $\mathrm{KC}$ were significantly more effective $(\mathrm{P}<0.05)$ for protocorm development than the other two culture media. In Habenaria macroceratitis and H. tenebrosa Stewart \& Kane (2006) and
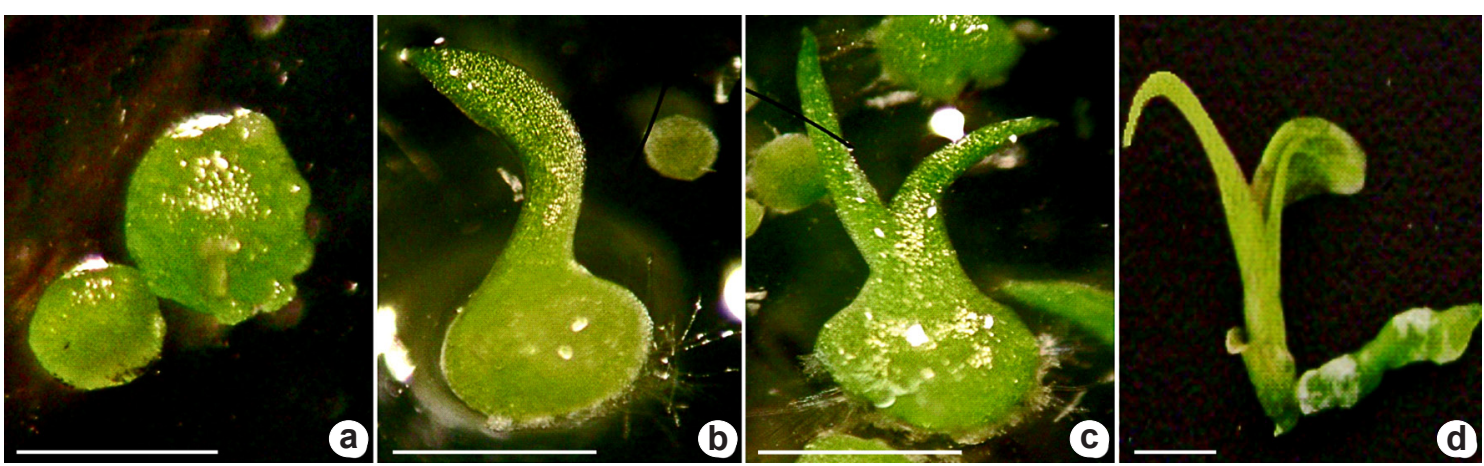

Figure 2 - Developmental stages in Catasetum macrocarpum protocorms - a. Stage 1 - swollen, green embryos (protocorm phase); b. Stage 2 - protocorm bearing one leaf. c. Stage 3 - protocorm bearing two leaves. d. Stage $4-$ seedling with leaves and one root. (Scale bars $=1 \mathrm{~mm}$ ). 


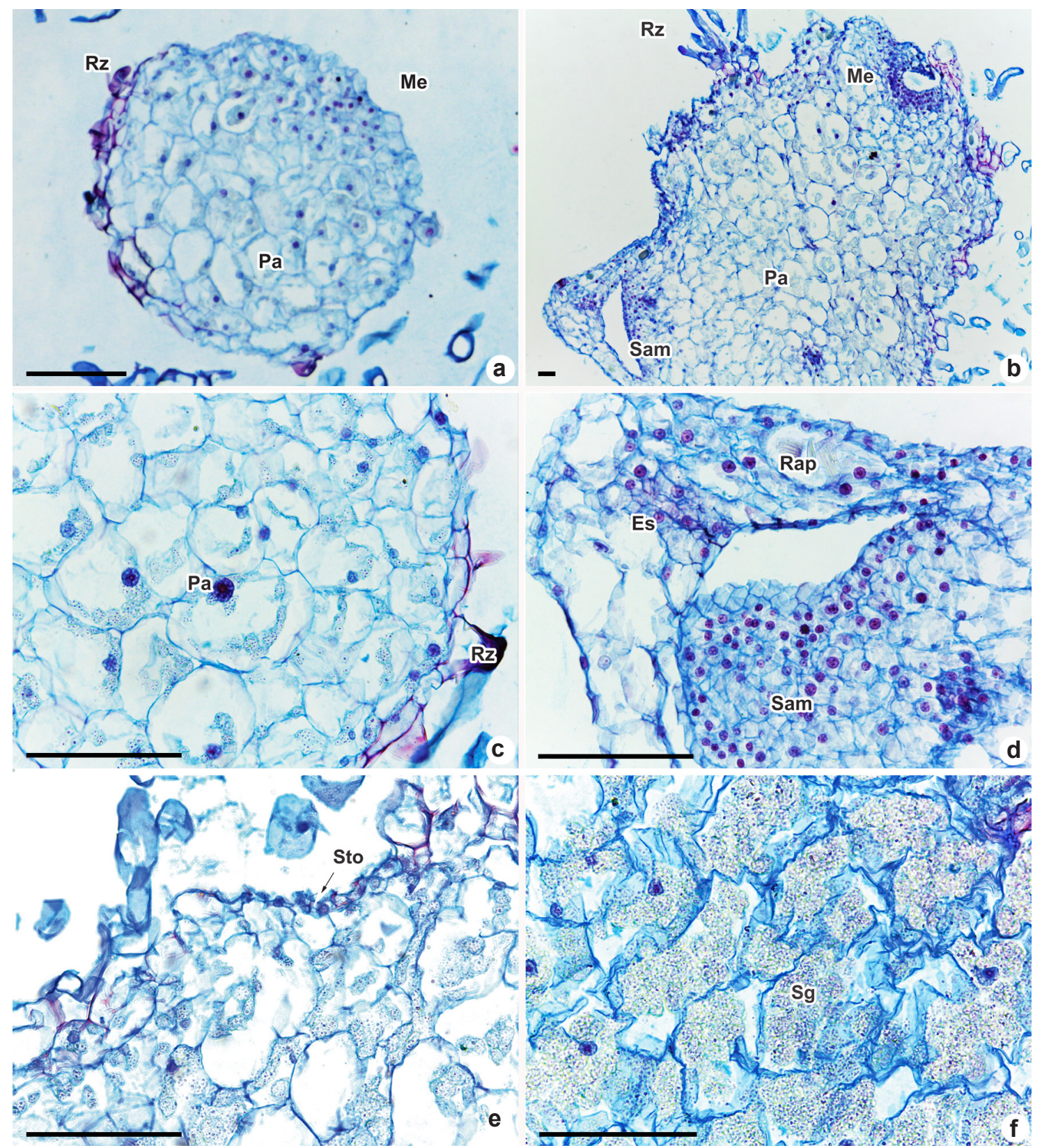

Figure 3 - a. Protocorm of Catasetum macrocarpum at stage 1, exhibiting a meristematic region with intense cell division; b. early cell differentiation in the upper and lower regions of the protocorm. Rhizoids are easily visible in the upper portion of the figure; c. detail of a rhizoid structure. A parenchymatous region is observed in the center; d. detail of an epidermal scale, where an idioblast containing raphides can be seen; e. detail of a stoma on the epidermis of a C. macrocarpum protocorm; f. starch grains in the cells of a protocorm. Es = epidermal scale; $\mathrm{Sam}=$ shoot apical meristem; $\mathrm{Pa}=$ parenchyma $\mathrm{Rap}=$ raphide $\mathrm{Rz}=$ rhizoid. $\mathrm{Sg}=$ starch grains; $\mathrm{Sto}=$ stoma . (Scale bars: $100 \mu \mathrm{m})$. 
Table 1 - Effects of Murashige \& Skoog (MS and 1/2MS), Knudson C (KC), and Vacin \& Went (VW) media, on the in vitro multiplication and initial growth of Catasetum macrocarpum.

\begin{tabular}{lcccc}
\hline \multirow{1}{*}{\multicolumn{1}{c}{ Variables }} & \multicolumn{4}{c}{ Culture Media } \\
\cline { 2 - 5 } & MS & $1 / 2 \mathrm{MS}$ & $\mathrm{KC}$ & $\mathrm{VW}$ \\
\hline Number of shoots/explant & $3.1 \mathrm{ab}^{*}$ & $5.1 \mathrm{a}$ & $1.5 \mathrm{bc}$ & $1.0 \mathrm{c}$ \\
Longest shoot length & $6.25 \mathrm{a}$ & $3.0 \mathrm{~b}$ & $2.15 \mathrm{~b}$ & $1.6 \mathrm{~b}$ \\
Number of roots/explant & $5.0 \mathrm{a}$ & $5.2 \mathrm{a}$ & $2.2 \mathrm{~b}$ & $2.4 \mathrm{~b}$ \\
Longest root length & $3.2 \mathrm{a}$ & $3.0 \mathrm{ab}$ & $2.0 \mathrm{~b}$ & $1.8 \mathrm{~b}$ \\
Leaf number/explant & $13.5 \mathrm{a}$ & $16.5 \mathrm{a}$ & $2.9 \mathrm{~b}$ & $2.6 \mathrm{~b}$ \\
Shoot dry mass (g) & $0.022 \mathrm{a}$ & $0.028 \mathrm{a}$ & $0.006 \mathrm{~b}$ & $0.010 \mathrm{~b}$ \\
Root dry mass (g) & $0.006 \mathrm{a}$ & $0.007 \mathrm{a}$ & $0.002 \mathrm{~b}$ & $0.007 \mathrm{a}$ \\
\hline
\end{tabular}

* Values followed by the same letter (in rows) are not significantly different according to the Tukey's test at $5 \%$ probability level.

Suzuki et al. (2009), respectively, also verified that VW provided the highest number of protocorms at more advanced stages of development when compared to other culture media. Fráguas et al. (2003) also reported that $\mathrm{KC}$ was the most effective medium for the initial growth of Cattleya labiata $\times$ Laelia itambana seedlings. Contrasting results were reported by Lo et al. (2004) for D. tosaense. They observed that MS and $1 / 2 \mathrm{MS}$ were more effective for protocorm development than were VW and $\mathrm{KC}$. It is possible that nutrient requirements in D. tosaense are higher than the other species mentioned, including Catasetum macrocarpum, especially in terms of nitrogen since MS is almost four times richer in this nutrient than $\mathrm{VW}$ and $\mathrm{KC}$ (total nitrogen content $[\mathrm{mM}]$ in $\mathrm{MS}=60.06$, in VW $=12.77$ and in $\mathrm{KC}=16.04$ ).

The results presented above revealed that the medium that provided the best germination response $(\mathrm{KC})$ was not the same one that stimulated the best protocorm development (VW). In H. tenebrosa, Suzuki et al. (2009) also verified that seed germination was better on $\mathrm{KC}$ and protocorm development 120 days after germination was more pronounced on VW. On the other hand, Dohling et al. (2008) reported that both germination and protocorm development in $D$. longicornu and $D$. formosum were found to be best on MS. In Bletia purpurea, high germination percentages were observed in all media tested but protocorm development was much greater on VW (Dutra et al. 2008). Taken together, these results clearly show that medium requirements for orchid germination and protocorm development vary among species.
Effect of culture media on multiplication and growth

The effects of culture media on the in vitro multiplication and growth of Catasetum macrocarpum using 120-day-old seedlings are shown in Table 1. The best medium for shoot proliferation was $1 / 2 \mathrm{MS}$ although it did not significantly differ from MS $(P<0.05)$. The number of shoots produced per explant in VW and $\mathrm{KC}$ was significantly lower than in $1 / 2 \mathrm{MS}$. Decruse et al. (2013), upon studying the in vitro propagation of Eulophia cullenii, verified that shoot proliferation was higher on $1 / 4 \mathrm{MS}$ and $\mathrm{KC}$ than on the other media surveyed. Different results were reported by Duan \& Yazawa (1994) for $\times$ Doriella Tiny (Doritis pulcherrima $\times$ Kingiella philippinensis). They found that the highest number of vegetative buds (which give rise to shoots) per inoculated explant was obtained on VW when compared to full-strength MS. In Epidendrum nocturnum, Silva et al. (2016) reported that KC was the best medium for shoot proliferation.

Leaf formation was higher on MS and $1 / 2 \mathrm{MS}$ than on $\mathrm{KC}$ and VW. Very similar results were detected by Abrão et al. (2014) in Cattleya loddigesii, that is, MS and $1 \frac{1}{2} \mathrm{MS}$ promoted a higher production of leaves than KC and VW. Suzuki et al. (2009) also observed that leaf formation in $H$. tenebrosa was greater in MS than in KC and VW. In Cattleya harrisoniana, no difference was detected between MS and $1 / 2 \mathrm{MS}$ in relation to leaf production (Schneiders et al. 2012). It has long been known that macronutrients, especially nitrogen, positively affect leaf production and growth (Belfort \& Haag 1983). Therefore, it is possible that the data 
obtained are related to the fact that MS is a nutrientrich medium.

Regarding root formation, MS and $1 / 2$ MS were also more effective than the other two media and MS provided significant results $(P<0.05)$ when compared to VW and KC. Rego-Oliveira \& Faria (2005) reported similar results; they detected that MS significantly stimulated the formation of new roots in Catasetum fimbriatum after six months of growth in vitro. On the other hand, those authors reported that $\mathrm{KC}$ was more suitable for root formation in Cyrtopodium paranaensis. In contrast to what was observed in the present study, Unemoto et al. (2007) revealed that MS was inhibitory to root formation in Oncidium nanum and Cattleya forbesii after eight months of culture.

In terms of root and shoot length (Tab. 1), the data showed that MS provided the best results for these two variables, especially for shoot length since this medium significantly $(P<0.05)$ promoted shoot elongation. The results reported by Rego-Oliveira \& Faria (2005) for C. fimbriatum after six months of growth in vitro were quite similar to the ones obtained in the present study since they detected that MS favored better shoot and root growth (in length) than VW and KC. In Cyrtopodium paranaensis, those authors reported that MS also provided the best result for shoot length whereas root length was more pronounced in KC. Suzuki et al. (2009) reported divergent results for $H$. tenebrosa, given that VW was the most effective medium for shoot and root length after six months of growth in vitro, while MS was the least effective for both parameters. Unemoto et al. (2007) also concluded that MS was the least suitable medium for shoot and root growth in length in O. nanum and Cattleya forbesii after eight months of culture.

No significant differences were detected among VW, MS and $1 / 2 \mathrm{MS}$ for root dry mass accumulation $(P<0.05)$. KC was the least favorable medium for this parameter. Regarding shoot dry mass, the best result was obtained in $1 / 2 \mathrm{MS}$, followed by MS, VW and KC. MS and $1 / 2 \mathrm{MS}$ provided significantly better results $(P<0.05)$ than VW and KC. Suzuki et al. (2009) reported that in $H$. tenebrosa, MS was the most suitable medium for dry mass accumulation. In O. baueri, MS was also the best medium for shoot dry mass production (Sorace et al. 2008).

When the influence of the relative amounts of nitrate and ammonium in the medium is considered, MS presents a higher nitrate: ammonium ratio than the other culture media investigated, which might have positively affected the results for root and shoot growth. Majerowics et al. (2000) reported that the relative growth rate of $C$. fimbriatum roots was higher when that ratio favored nitrate $(3: 2)$. These authors did not find significant differences in terms of shoot growth among the different nitrate: ammonium ratios assessed. The results obtained for C. macrocarpum, nevertheless, clearly demonstrated that the presence of a higher nitrate concentration significantly favored shoot growth. Shoot dry mass accumulation also benefited significantly from the higher nitrate: ammonium ratio of MS and $1 / 2 \mathrm{MS}$ culture media. In C. fimbriatum, Majerowics et al. (2000) did not observe significant differences in terms of root and shoot dry mass accumulation among the various inorganic nitrogen sources and concentrations tested. Altogether, these results show that the response to exogenously applied nitrogen also differs among species and point out to the fact that studies to detect the specific nitrogen requirements are very important not only to understand the in vitro organogenesis of plants (Ramage \& Williams, 2002) but also their physiological adaptations to natural environments as stated by Adams \& Attiwill (1982).

Overall, $1 / 2 \mathrm{MS}$ provided the best results for most growth variables analyzed. This result could possibly be related to the fact that $C$. macrocarpum is epiphytic and naturally grows in nutrient-poor environments and that some of the salts present in the other media (or their concentration) may have negatively affected its growth in vitro. Therefore, this medium was selected for the following experiment.

\section{Effects of BA and NAA on}

multiplication and growth

The results of the effects of different combinations of BA and NAA on the multiplication and growth of C. macrocarpum (Tab. 2) revealed that $1 \mathrm{mg} \mathrm{L}^{-1} \mathrm{BA}$ alone was the best treatment for shoot proliferation, although significant differences $(P<0.05)$ were not detected among this treatment, the control (no growth regulators) and $0.5 \mathrm{mg} \mathrm{L}^{-1}$ BA. Roy et al. (2011) reported that $0.85 \mathrm{mg} \mathrm{L}^{-1} \mathrm{BA}$ was the treatment that best favored shoot formation in Vanda coerulea and that the addition of $1 \mathrm{mg} \mathrm{L}^{-1}$ of NAA together with that BA concentration did not alter shoot production. In $O$. tigrinum, $1 \mathrm{mg}$ $\mathrm{L}^{-1} \mathrm{BA}$ in combination with $0.1 \mathrm{mg} \mathrm{L}^{-1} \mathrm{NAA}$ was the best treatment for shoot proliferation (Rosas 
Table 2 - Effects of benzyladenine (BA) and naphthaleneacetic acid (NAA) on the multiplication and growth of Catasetum macrocarpum after 120 days of in vitro culture. NS = number of shoots/explant; SL = longest shoot length; $\mathrm{NR}=$ number of roots/explant; $\mathrm{RL}=$ longest root length; $\mathrm{SDM}=$ shoot dry mass; RDM = root dry mass.

\begin{tabular}{ccccccc}
\hline BA/NAA $\left(\mathbf{m g ~ L}^{-1}\right)$ & NS & SL $(\mathbf{c m})$ & NR & RL $(\mathbf{c m})$ & SDM $(\mathbf{g})$ & RDM $(\mathbf{g})$ \\
\hline $0 / 0$ & $3.8 \mathrm{a}^{*}$ & $6.3 \mathrm{~b}$ & $3.8 \mathrm{~b}$ & $2.2 \mathrm{~b}$ & $0.034 \mathrm{~b}$ & $0.008 \mathrm{~b}$ \\
$0 / 0.5$ & $1.9 \mathrm{~b}$ & $9.9 \mathrm{a}$ & $6.1 \mathrm{a}$ & $6.1 \mathrm{a}$ & $0.059 \mathrm{a}$ & $0.018 \mathrm{a}$ \\
$0 / 1$ & $1.6 \mathrm{~b}$ & $7.8 \mathrm{ab}$ & $3.9 \mathrm{~b}$ & $3.8 \mathrm{~b}$ & $0.033 \mathrm{~b}$ & $0.015 \mathrm{a}$ \\
$0.5 / 0$ & $3.7 \mathrm{a}$ & $3.5 \mathrm{c}$ & $1.9 \mathrm{c}$ & $0.7 \mathrm{c}$ & $0.052 \mathrm{a}$ & $0.003 \mathrm{c}$ \\
$0.5 / 0.5$ & $1.8 \mathrm{~b}$ & $2.9 \mathrm{~d}$ & $1.9 \mathrm{c}$ & $0.3 \mathrm{~d}$ & $0.028 \mathrm{~b}$ & $0.001 \mathrm{c}$ \\
$0.5 / 1$ & $1.8 \mathrm{~b}$ & $2.5 \mathrm{~d}$ & $1.7 \mathrm{c}$ & $0.5 \mathrm{c}$ & $0.030 \mathrm{~b}$ & $0.002 \mathrm{c}$ \\
$1 / 0$ & $4.1 \mathrm{a}$ & $4.1 \mathrm{c}$ & $0.6 \mathrm{~d}$ & $0.2 \mathrm{~d}$ & $0.042 \mathrm{a}$ & $0.001 \mathrm{c}$ \\
$1 / 0.5$ & $2.3 \mathrm{~b}$ & $4.3 \mathrm{c}$ & $0.8 \mathrm{~d}$ & $0.3 \mathrm{~d}$ & $0.057 \mathrm{a}$ & $0.001 \mathrm{c}$ \\
$1 / 1$ & $2.7 \mathrm{~b}$ & $2.0 \mathrm{~d}$ & $0.3 \mathrm{~d}$ & $0.2 \mathrm{~d}$ & $0.033 \mathrm{~b}$ & $0.001 \mathrm{c}$ \\
\hline
\end{tabular}

* Values followed by the same letter (in rows) are not significantly different according to the Tukey's test at 5\% probability level.

\& Garcia 2011). In Encyclia mariae, Diaz \& Alvarez reported that shoot formation was two- to threefold higher when leaf explants were cultured on media supplemented with auxins and BA. In C. macrocarpum the addition of NAA strongly inhibited shoot formation. These results clearly demonstrate that orchid species exhibit different responses to hormone concentrations in culture media. Moreover, the simultaneous addition of an auxin and a cytokinin to the culture medium can favor the process of shoot formation in some orchid species, which was not the case of $C$. macrocarpum in the present study. It is necessary to point out that in this investigation the addition of growth regulators was only tested in the presence of $2 \%$ sucrose.

$\mathrm{NAA}$ at $0.5 \mathrm{mg} \mathrm{L}^{-1}$ was the best treatment for shoot growth in terms of length but it did not significantly differ from $1 \mathrm{mg} \mathrm{L}^{-1} \mathrm{NAA}(P<0.05)$ despite a decrease being observed at the latter concentration. It was verified that when 0.5 or 1 mg L $\mathrm{L}^{-1}$ NAA was used in combination with BA, shoot length was significantly inhibited. Souto et al. (2010) also reported that $0.5 \mathrm{mg} \mathrm{L}^{-1}$ NAA favored shoot length in Cattleya bicolor. These results are not surprising since one of the roles of auxins is to stimulate cell expansion which promotes growth in length. However, some studies revealed that orchid shoot growth in length can benefit from the combination of an auxin and a cytokinin such as BA, as was reported by Diaz \& Alvarez (2009) for E. mariae, by Roy et al. (2011) for V. coerulea, and by Rosas \& Garcia (2011) for O. tigrinum.

Root formation was significantly promoted by $0.5 \mathrm{mg} \mathrm{L}^{-1} \mathrm{NAA}$ and no statistical difference was detected between $1 \mathrm{mg} \mathrm{L}^{-1}$ NAA and the control treatment. Inhibition of this parameter was observed at all other treatments. In Cattleya bicolor, Souto et al. (2010) also verified that $0.5 \mathrm{mg} \mathrm{L}^{-1}$ NAA was the best auxin treatment for root formation and that lower or higher NAA concentrations did not favor the process. The presence of BA, regardless of NAA concentration, inhibited root formation in C. macrocarpum. In V. coerulea, BA did not inhibit root formation (Roy et al. 2011). NAA at $0.5 \mathrm{mg} / \mathrm{L}$ was also the best treatment for root growth in length since it provided a significant increase in the length of roots $(P<0.05)$ when compared to the other treatments. Souto et al. (2010) also reported that $0.5 \mathrm{mg} / \mathrm{L}$ NAA was the best auxin concentration for root growth in length. Contrasting results were reported by Roy et al. (2011) for V. coerulea. They verified that relatively high BA concentrations in the presence of auxins favored root length.

Regarding shoot and root dry mass, $0.5 \mathrm{mg}$ $\mathrm{L}^{-1}$ NAA also promoted the best results, although this treatment did not significantly differ from 0.5 and $1.0 \mathrm{mg} \mathrm{L}^{-1} \mathrm{BA}$; neither did it differ significantly from the combination of $1 \mathrm{mg} \mathrm{L}^{-1} \mathrm{BA}$ and $0.5 \mathrm{mg}$ $\mathrm{L}^{-1}$ NAA in terms of shoot dry mass nor from 1 mg L ${ }^{-1}$ NAA when root dry mass is concerned. In Cattleya bicolor, Souto et al. (2010) reported that $0.5 \mathrm{mg} \mathrm{L}^{-1} \mathrm{NAA}$ was the best treatment for shoot dry mass accumulation and that higher concentrations were inhibitory. These authors also verified an increase in root dry mass at NAA concentrations of up to $1 \mathrm{mg} \mathrm{L}^{-1}$. It is important to highlight that root number and size as well as the amount of dry mass accumulated by roots are crucial for the 
survival of orchid plants produced in vitro during the acclimatization phase.

\section{Anatomical studies}

The anatomical studies revealed that, from a histological perspective, the four protocorm developmental stages described above are not easily distinguishable. Initially the seed, made up of a mass of undifferentiated cells, swells and gives rise to a protocorm (Fig. 3a). Then, cells of the upper and lower regions of the protocorm begin to differentiate. The cells in the upper region originate the shoot apical meristem and those of the lower region produce rhizoids and in the future the root system (Fig. 3b). The central portion of the protocorm is composed of parenchyma cells. It is important to mention that not all protocorms present on the culture medium analyzed developed uniformly, that is, it was possible to find protocorms of different developmental stages 90 days after the onset of germination.

The presence of rhizoids, epidermal scales and stomata was observed in the studied protocorms (Figs. 3b, 3d and 3e, respectively). The rhizoids, originated from epidermis histodifferentiation, play a role in the initial support of the protocorm as well as in the uptake of nutrients (Arditti, 1992). Under in vitro conditions, the nutrients required for protocorm development are provided by the culture medium and rhizoids may represent important structures but that are not necessarily essential for nutrient uptake (Kraus et al. 2006). In Figure 3f, a great amount of starch (in the form of grains) can be seen. Purves \& Hadley (1976) also observed that starch accumulated in asymbiotic protocorms of Goodyera repens nine weeks (63 days) after sowing seeds onto a culture medium containing Pfeffer's mineral solution. The results observed here for C. macrocarpum are in accordance with those reported for $G$. repens. Upon studying the germination of Cypripedium acaule seeds in vitro, Leroux et al. (1997) verified that lipid and protein reserves present in the embryo completely disappeared during the initial stages of protocorm development and were replaced by a large amount of starch. Lee et al. (2013) also reported that protein deposits were no longer visible in developing protocorms of Phalaenopsis Taisuco Yellow a few weeks after sowing, and that many starch grains could be seen instead.

Some protocorms exhibited leaf primordia originated from the shoot apical meristem, which can possibly indicate a phase transition: from Stage
1 [protocorm] to Stage 2 [protocorm bearing one leaf] (Fig. 4c). A well-defined procambium in the central portion of the protocorm can also be observed in this figure. This procambium develops in the direction of a younger leaf primordium as well as towards the lower region of the protocorm where the root system will be established. At stage 2 , the growth regions are clearly evident and leaf primordia at different developmental stages can be observed (Fig. 4a). The detail of Figure $4 \mathrm{~b}$ shows the shoot apical meristem and a leaf primordium containing raphide-rich idioblasts which protect the meristematic region. Kraus et al. (2006) reported that three weeks after seed inoculation in vitro, $C$. pileatum protocorms exhibited formation of bud primordia showing differentiation of leaf structures.

The C. macrocarpum protocorms observed in the present study exhibited a meristematic region in the upper portion, which was denser in small cells. As is common in the germination of orchid seeds, the formation of the first leaves is prior to root emergence. Epidermal scales were also observed in the protocorms of C. macrocarpum (Fig. 4c). They are probably related to the protection of the shoot apical meristem since they contain raphides. Epidermal scales have been described by a few authors as leaf adaptations (Aoyama \& Sajo 2003; Scatena \& Segecin 2005).

The histological observations of Stage 3 protocorms corroborated the morphological characteristics previously described. They exhibited two leaves and yet no root formation was visible (Fig. 4d). At Stage 4, the growth regions, clearly distinct, showed high mitotic activity. Root formation is observed at this phase, which marks the end of the protocorm phase and the beginning of the seedling stage. Seedlings exhibited one or two roots and a connection of their vascular tissues with those of the leaf in formation (Fig. 4e), making it evident that the roots are of endogenous origin. Figure $4 \mathrm{f}$ shows the details of a root cap. A transection of the root is shown in Figure 4g. It is also possible to detect the beginning of velamen formation. Figure $4 \mathrm{~h}$ exhibits details of the root vascular cylinder showing several alternate xylem and phloem poles, which characterize polyarchous roots. In the center of the root there is a pith with a typical siphonostele. Although each species is unique and, thus, exhibits specific anatomical characteristics, in general the structures observed in C. macrocarpum are similar to those of other species of Orchidaceae. 

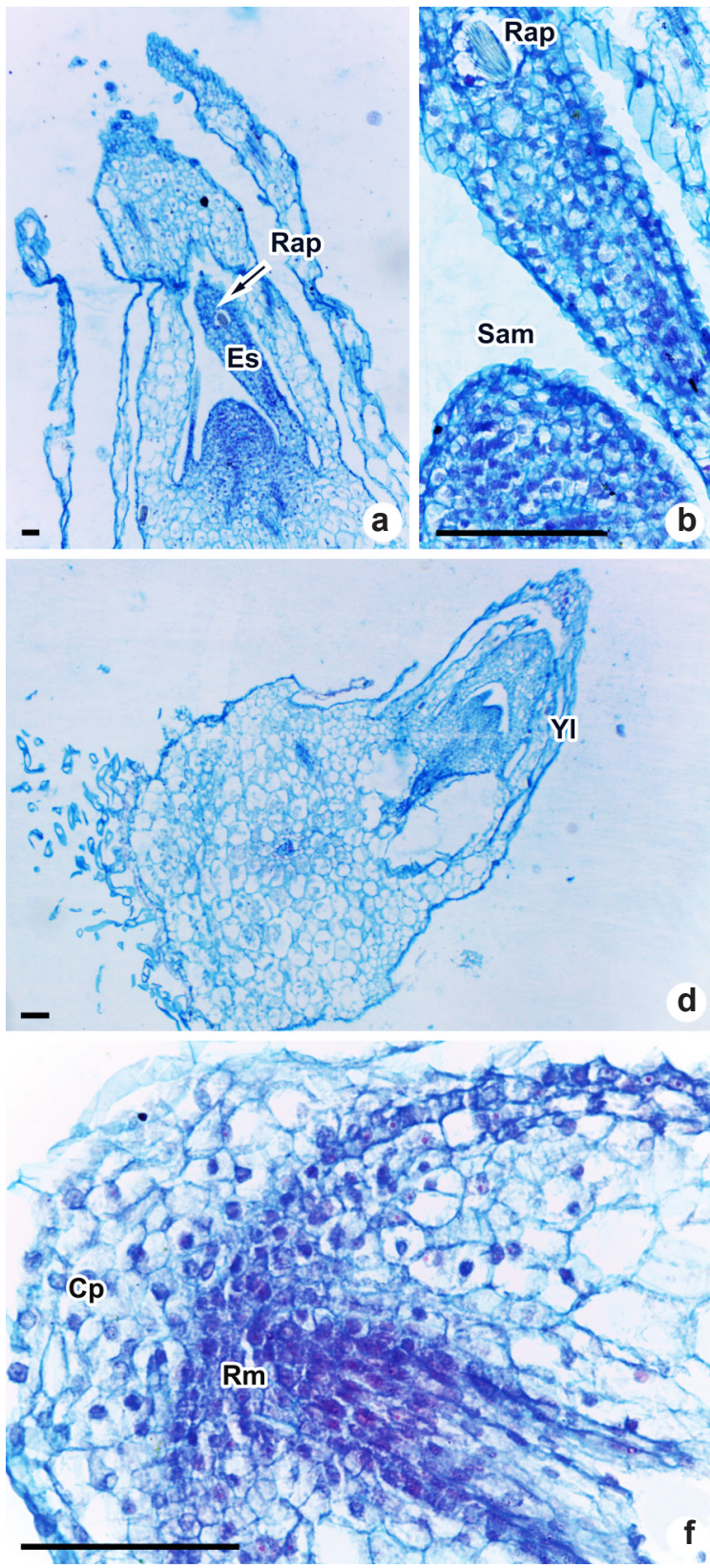

d
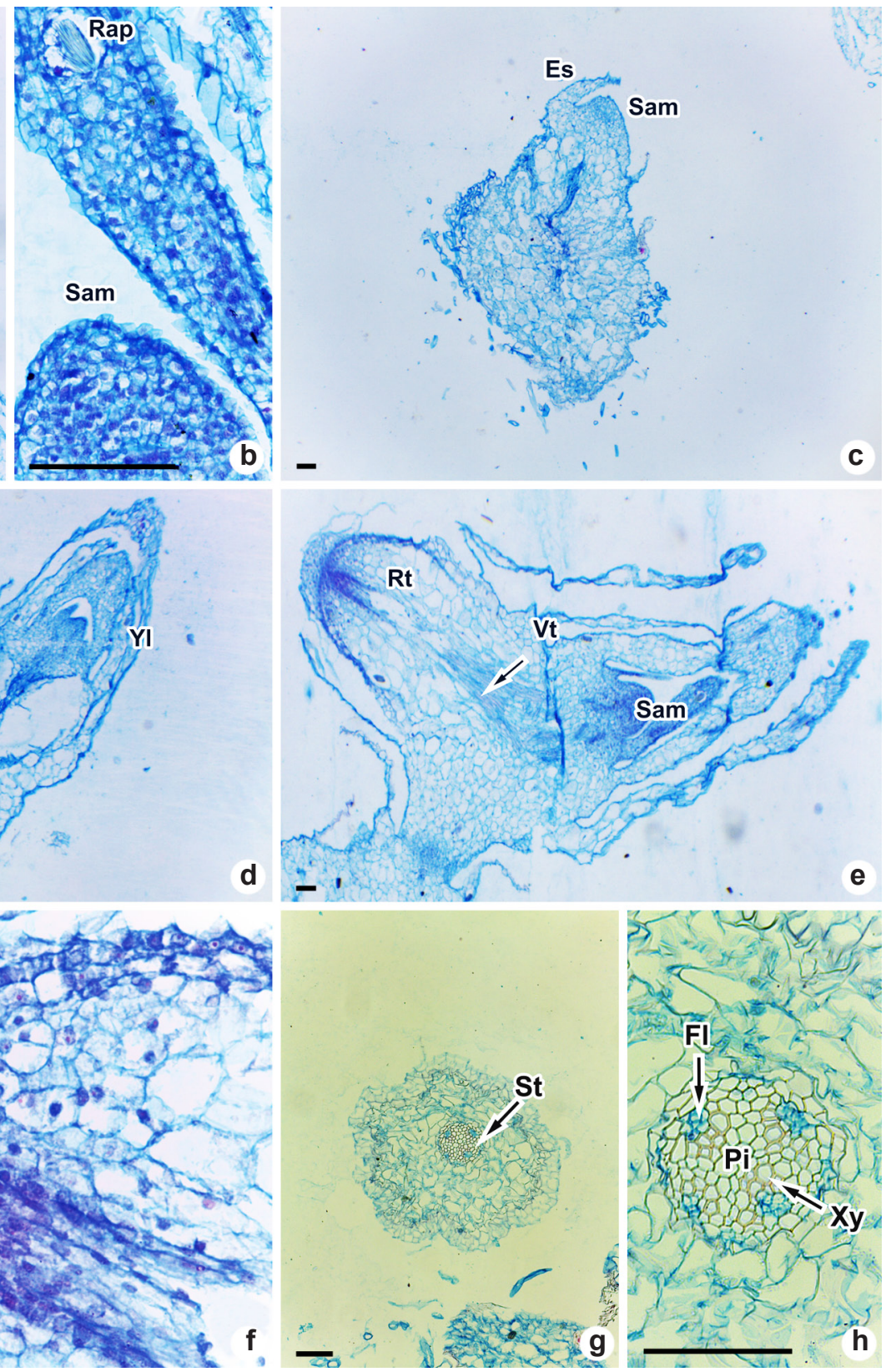

Figure 4 - a. Leaves of Catasetum macrocarpum at different developmental stages. A detail can be seen in b, which shows that the leaf growth region is protected by a raphide-containing epidermal scale; c. leaf scale protecting the shoot apical meristem; d. stage 3 protocorm showing a differentiated leaf; e. seedling at an initial stage of development showing a root, leaf primordia and young leaves; f. detail of a root tip exhibiting the meristematic region and root cap; g. transection of a root; h. detail of a root exhibiting the vascular cylinder. $\mathrm{Cp}=$ root cap; Es $=$ epidermal scale $; \mathrm{St}=$ stele $; \mathrm{Yl}=$ young leaf; $\mathrm{Pl}=$ phloem; $\mathrm{Sam}=$ shoot apical meristem; $\mathrm{Pi}=$ pith; $\mathrm{Rm}=$ root meristem; $\mathrm{Rt}=$ root $\mathrm{Rap}=$ raphide; $\mathrm{Vt}=$ vascular tissue; $\mathrm{Xy}=\mathrm{xylem} .($ Scale bars: $100 \mu \mathrm{m})$. 


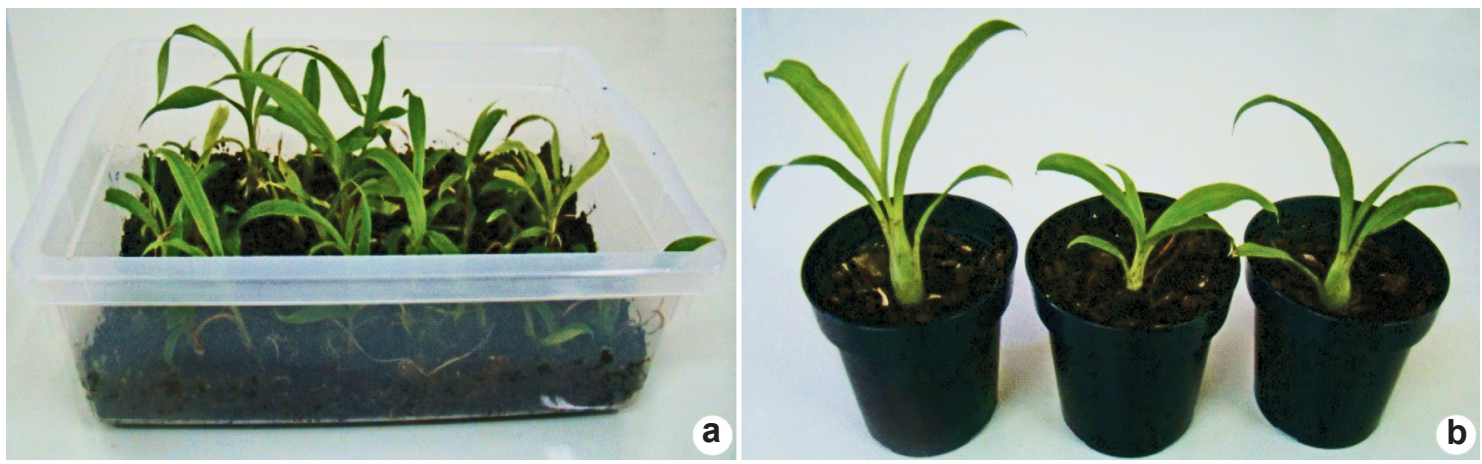

Figure 5 - a. Catasetum macrocarpum plants at the first acclimatization phase (plastic containers $10 \mathrm{~cm}$ height $\times$ $19 \mathrm{~cm}$ width $\times 29 \mathrm{~cm}$ length); b. C. macrocarpum plants in individual pots at the third acclimatization phase (plastic pots $7 \mathrm{~cm}$ height $\times 6 \mathrm{~cm}$ basal diameter).

\section{Acclimatization}

Acclimatization is a critical stage of the in vitro propagation of orchid species (Ortega-Loeza et al. 2011) since the transfer to natural conditions can be detrimental to plants if the process is not carefully conducted. The selection of a suitable substrate is one of the important aspects that need to be addressed to ensure plant survival and development during acclimatization. Great differences were not detected between the potting mixes used during the first acclimatization phase of $C$. macrocarpum. The survival rates observed were $93.3 \%$ for Bioplant Prata and for Bioplant Prata-sphagnum (1:1), and $91.7 \%$ for Bioplant Prata-sphagnum (2:1).

At the end of the second phase $96.6 \%$ of the plants survived. Sphagnum was substituted for Ouro Negro at the second and third phases because it is a much coarser substrate and roots can be better hardened and, thus we believe plants can respond more efficiently when transferred to phorophytes in the natural environment. Ouro Negro is also commonly used by commercial orchid growers in Tocantins. Sousa et al. (2015) reported that the greatest survival percentage (74\%) of Brassavola tuberculata plants during acclimatization was achieved when using sphagnum as a substrate when compared to coconut fiber and a mix of sphagnum and coconut fiber $(1: 1 \mathrm{v} / \mathrm{v})$. They argued that due to its physical properties, sphagnum provided better water retention as well as adequate porosity. In the present study, the addition of sphagnum to Bioplant Prata did not affect survival of C. macrocarpum plants. Figure 5 a shows plants at the first and third acclimatization phases.
Dorneles \& Trevelin (2011) obtained 53\% survival of Cattleya intermedia in sphagnum and they also point to the fact that this substrate exhibits good water-holding capacity. In the case of the present study, mixing sphagnum with Bioplant Prata was advantageous to $C$. macrocarpum survival when compared to the two studies mentioned above in which sphagnum was used alone or in combination with coconut fiber. It is important to mention, nonetheless, that Bioplant Prata is enriched with mineral nutrients, including calcium and magnesium.

Sixty days after transfer to shade-house conditions (third phase, Fig. 5b), the survival rate was $75 \%$. This last stage was the most crucial for plant survival since plants were transferred to a more stressful environment. Keithly et al. (1991) reported that during the first six months after transfer of orchid plants to greenhouse conditions, plant loss can reach $50 \%$. As the results presented herein refer to only 60 days after transfer to a shadehouse environment, it is possible that a decrease in survival percentage might occur after a longer period of time. Franco et al. (2007) also verified that transfer of micropropagated plants of Cattleya trianae to greenhouse conditions resulted in only $47 \%$ survival of the plants. These authors state that greenhouses have substantially lower relative humidity, higher light intensities and non-sterile environments that are stressful to micropropagated plants when compared to in vitro conditions. The same might be said of shade-house conditions where C. macrocarpum plants were kept during the third phase of the acclimatization process. 
In summary, the results presented above revealed that the most favorable medium for germination of C. macrocarpum seeds was not the one that promoted the best protocorm and seedling development. Therefore, each developmental stage of this species in vitro requires a different culture medium with specific nutrient concentrations. In light of these findings, $\mathrm{KC}$ is the ideal medium for germination of C. macrocarpum seeds. Thirty to forty days following germination, protocorms should be transferred to VW medium for seedling formation and development. For multiplication and growth, 120-day-old seedlings can be grown on $1 / 2 \mathrm{MS}$ supplemented with $1 \mathrm{mg} \mathrm{L}^{-1} \mathrm{BA}$ and then transferred to the same medium enriched with 0.5 $\mathrm{mg} \mathrm{L}^{-1}$ for root proliferation and development. Acclimatization of C. macrocarpum plants can be successfully accomplished by transferring plants produced in vitro to community pots containing Bioplant Prata substrate for 30 days, followed by their transfer to individual pots containing a 2:1 mix of Ouro Negro and Bioplant Prata substrates where they should be kept for another 30 days. After this period plants can be taken to a shade-house with $50 \%$ retention of solar radiation.

The anatomical analysis revealed that the ontogeny of the initial stages of C. macrocarpum development, from a histological perspective, do not always coincide with the morphological phases described since, as expected, tissue formation takes place before organs can be visualized. Although the initial formation of leaf and root tissues depicted in this investigation is unique to the species studied, it corroborates other studies related to orchid development and shows that the observed patterns are peculiar to this group of plants.

\section{Acknowledgments}

The authors thank Fundação Banco do Brasil for financial support and the Federal University of Tocantins (Propesq) for a research grant awarded to the first author.

\section{References}

Abrão MCR, Jorge J, Pescador R, Ferreira WM \& Suzuki RM (2014) Germinação de sementes e desenvolvimento in vitro de plântulas de Cattleya loddigesii Lindl. (Orchidaceae). Revista Brasileira de Biociências 12: 141-147.

Adams MA \& Attiwill PM (1982) Nitrate reductase activity and growth response of forest species to ammonium and nitrate sources of nitrogen. Plant and Soil 66: 373-381.
Aoyama EM \& Sajo MG (2003) Estrutura foliar de Aechmea Ruiz \& Pav. subgênero Lamprococcus (Beer) Baker e espécies relacionadas (Bromeliaceae). Brazilian Journal of Botany 26: 461-473.

Arditti J (1967) Factors affecting the germination of orchid seeds. Botanical Review 33: 1-97.

Arditti J (1992) Fundamentals of orchid biology. John Wiley and Sons, New York. 691p.

Belfort CC \& Haag HP (1983) Nutrição mineral de hortaliças - Carência de macronutrientes em cebolinha (Allium schoenoprasum). Annals of Esalq 40: 221-234.

Decruse SW, Reny N, Shylajakumari S \& Krishnan PN (2013) In vitro propagation and field establishment of Eulophia cullenii (Wight) B1., a critically endangered orchid of Western Ghats, India through culture of seeds and axenic seedling-derived rhizomes. In Vitro Cellular and Developmental Biology - Plant 49: 520-528.

Diaz MSS \& Alvarez CC (2009) Plant regeneration through direct shoot formation from leaf cultures and from protocorm-like bodies derived from callus of Encyclia mariae (Orchidaceae), a threatened Mexican orchid. In Vitro Cellular and Developmental Biology - Plant 45:162-170.

Dohling S, Kumaria S \& Tandon P (2008) Optimization of nutrient requirements for asymbiotic seed germination of Dendrobium longicornu Lindl. and D. formosum Roxb. Proceedings of the Indian National Science Academy 74: 167-171.

Dorneles LT \& Trevelin V (2011) Aclimatização e reintrodução de Cattleya intermedia Graham ex Hook (Orchidaceae) obtidas por propagação in vitro. Iheringia, Série Botânica 66: 167-174.

Duan JX \& Yazawa S (1994) Induction of floral development in x Doriella Tiny (Doritis pulcherrima $\mathrm{x}$ Kingiella philippinensis). Scientia Horticulturae 59: 253-264.

Dutra D, Johnson TR, Kauth PJ, Stewart SL, Kane ME \& Richardson L (2008) Asymbiotic seed germination, in vitro seedling development, and greenhouse acclimatization of the threatened terrestrial orchid Bletia purpurea. Plant Cell Tissue and Organ Culture 94: 11-21.

Engelmann F (2011) Use of biotechnologies for the conservation of plant biodiversity. In Vitro Cellular and Developmental Biology - Plant 47: 5-16.

Fay MF (1992) Conservation of rare and endangered plants using in vitro methods. In Vitro Cellular and Developmental Biology - Plant 28: 1-4.

Figueiredo MA, Santos FM, Silva JOC, Costa FHS \& Pasqual M (2007) Variação no meio de cultura sobre o crescimento in vitro em hibridos de orquideas. Revista Brasileira de Biociências 5: 294-296.

Fráguas CB, Villa F, Souza AV, Pasqual M \& Dutra LF (2003) Crescimento in vitro de plântulas de orquídea 
oriundas da hibridação entre Cattleya labiata e Laelia itambana. Revista Ceres 50: 719-726.

Franco M, Guevara G, Mesa N \& Urueña G (2007) Hardening of the national flower of Colombia, the threatened Cattleya trianae (Orchidaceae), from in vitro culture with previous invigoration phase. International Journal of Tropical Biology 55: 681-691.

Hossain MM, Sharma M, Silva JAT \& Pathak P (2010) Seed germination and tissue culture of Cymbidium giganteum Wall. ex Lindl. Scientia Horticulturae 123: 479-487.

Jensen WA (1962) Botanical histochemistry. W.H. Freeman, San Francisco. 408p.

Johansen DA (1940) Plant microtechnique. McGrawHill, New York. 423p.

Kauth PJ, Vendrame WA \& Kane ME (2006) In vitro seed culture and seedling development of Calopogon tuberosus. Plant Cell Tissue and Organ Culture 85: 91-102.

Keithly JH, Jones DP \& Yokoyama H (1991) Survival and growth of transplanted orchid seedlings enhanced by DCPTA. HortScience 26: 1284-1286.

Knudson L(1946) A new nutrient solution for germination of orchid seeds. American Orchid Society Bulletin 15: 214-217.

Kraus JE, Kerbauy GB \& Monteiro WR (2006) Desenvolvimento de protocormos de Catasetum pileatum Rchb.f. in vitro: aspectos estruturais e conceituais. Hoehnea 33: 177-184.

Lee YI, Hsu ST \& Yeung EC (2013) Orchid protocormlike bodies are somatic embryos. American Journal of Botany 100: 2121-2131.

Leroux G, Barabi D \& Vieth J (1997) Morphogenesis of the protocorm of Cypripedium acaule (Orchidaceae). Plant Systematics and Evolution 205: 53-72.

Lo SF, Nalawade SM, Kuo CL, Chen CL \& Tsay HS (2004) Asymbiotic germination of immature seeds, plantlet development and ex vitro establishment of plants of Dendrobium tosaense Makino - a medicinally important orchid. In Vitro Cellular and Developmental Biology - Plant 40: 528-535.

Majerowicz N, Kerbauy GB, Nievola CC \& Suzuki RM (2000) Growth and nitrogen metabolism of Catasetum fimbriatum (orchidaceae) grown with different nitrogen sources. Environmental and Experimental Botany 44: 195-206.

Manrique JP, Lizarazo CF \& Silva AS (2005) Evaluation of the effect of three growth regulators in the germination of Comparettia falcata seeds under in vitro conditions. In Vitro Cellular and Developmental Biology - Plant 41: 838-843.

Menezes LC (2004) Orquídeas do Planalto Central Brasileiro. Edições IBAMA, Brasília. 304p.

Murashige T \& Skoog F (1962) A revised medium for rapid growth and bioassays with tobacco tissue cultures. Physiologia Plantarum 15: 473-497.
Ortega-Loeza MM, Garciglia RS, Alonso CG \& Díaz IA (2011) Acclimatization of the endangered Mexican epiphytic orchid, Laelia speciosa (H.B.K.) Schltr. European Journal of Environmental Science 1: 48-54.

Panwar D, Ram K \& Shekhawat HNS (2012) In vitro propagation of Eulophia nuda Lindl., an endangered orchid. Scientia Horticulturae 139: 46-52.

Pasqual M, Ramos JD, Hoffmann A \& Carvalho GR (1997) Cultura de tecidos vegetais: tecnologia e aplicações. UFLA/FAEP, Lavras. 127p.

Paul S, Kumaria S \& Tandon P (2012) An effective nutrient medium for asymbiotic seed germination and large-scale in vitro regeneration of Dendrobium hookerianum, a threatened orchid of northeast India. AoB Plants: plr032 doi:10.1093/aobpla/plr032

Ponert J, Figura T, Vosolsobe S, Lipavska H, Vohnik M \& Jersakkova J (2013) Asymbiotic germination of mature seeds and protocorm development of Pseudorchis albida (Orchidaceae) are inhibited by nitrates even at extremely low concentrations. Botany 91: 662-670.

Purves S \& Hadley G (1976)The physiology of symbiosis in Goodyera repens. New Phytologist 77: 689-696.

Raghavan V \& Torrey JG (1964) Inorganic nitrogen nutrition of the seedling of the orchid Cattleya. American Journal of Botany 51: 264-274.

Ramage CM \& Williams RR (2002) Inorganic nitrogen requirements during shoot organogenesis in tobacco leaf discs. Journal of Experimental Botany 53: 1437-1443.

Rego-Oliveira LV \& Faria RT (2005) In vitro propagation of Brazilian orchids using traditional culture media and commercial fertilizers formulations. Acta Scientia Agronômica 27: 1-5.

Rosas MM \& Garcia RB (2011) In vitro regeneration through direct organogenesis from protocorms of Oncidium tigrinum Llave \& Lex. (Orchidaceae), an endemic and threatened Mexican species. HortScience 46: 1132-1135.

Roy AR, Patel RS, Patel VV, Sajeev S \& Deka C (2011) Asymbiotic seed germination, mass propagation and seedling development of Vanda coerulea Griff ex Lindl. (Blue Vanda): an in vitro protocol for an endangered orchid. Scientia Horticulturae 128: 325-331.

Scatena VL \& Segecin S (2005) Anatomia foliar de Tillandsia L. (Bromeliaceae) dos Campos Gerais, Paraná, Brasil. Brazilian Journal of Botany 28: 635-649.

Schneiders D, Pescador R, Booz MR \& Suzuki RM (2012) Germinação, crescimento e desenvolvimento in vitro de orquídeas (Cattleya spp. Orchidaceae). Revista Ceres 59: 185-191.

Silva CS, Araújo LG, Sousa KCI, Carvalho JCB, Gonçalves LA \& Carneiro LL (2016) Cultivo in vitro de Epidendrum nocturnum (Orchidaceae) ocorrente 
no Cerrado da Região Centro-Oeste. Rodriguésia 67: 1083-1091.

Sorace M, Faria RT, Damasceno Junior CV, Gomes GP, Barbosa CM, Vieira FGN, Silva GL, Takahashi LSA \& Schnitzer JA (2008) Crescimento in vitro de Oncidium baureri (Orchidaceae) em diferentes concentrações de macronutrientes e sacarose. Semina: Ciências Agrárias 29: 775-782.

Sousa GG, Rosa YBCJ, Macedo MC \& Soares JS (2015) Aclimatização de Brassavola tuberculata com a utilização de ANA em diferentes substratos. Horticultura Brasileira 33: 208-215.

Souto JS, Morimoto JM, Ferreira WM, Nakabashi M \& Suzuki RM (2010) Efeitos do ácido naftalenoacético no desenvolvimento in vitro de Cattleya bicolor Lindl. (Orchidaceae). Revista Brasileira de Biociências 8: 179-185.

Spoerl E (1948) Amino acids as sources of nitrogen for orchid embryos. American Journal of Botany 35: $88-95$.

Stewart J (1989) Orchid propagation by tissue culture techniques - past, present and future. In: Pritehard HW (ed.) Modern methods in orchid conservation: the role of physiology, ecology and management. Cambridge University Press, Cambridge. Pp. 147-183.

Stewart SK \& Kane ME (2006) Asymbiotic seed germination and in vitro seedling development of Habenaria macroceratitis (Orchidaceae), a rare Florida terrestrial orchid. Plant Cell Tissue and Organ Culture 86: 147-158.

Suzuki RM, Almeida V, Pescador R \& Ferreira WM (2010) Germinação e crescimento in vitro de
Cattleya bicolor Lindley (Orchidaceae). Hoehnea 37: 731-742.

Suzuki RM, Moreira VC, Nakabashi M \& Ferreira WM (2009) Estudos da germinação e crescimento in vitro de Hadrolaelia tenebrosa (Rolfe) Chiron \& V.P. Castro (Orchidaceae), uma espécie da flora brasileira ameaçada de extinção. Hoehnea 36: 657-666.

Suzuki RM, Moreira VC, Pescador R \& Ferreira WM (2012) Asymbiotic seed germination and in vitro seedling development of the threatened orchid Hoffmannseggella cinnabarina. In Vitro Cellular and Developmental Biology - Plant 48: 500-511.

Unemoto LK, Faria RT, Vieira AOS \& Danilo RJD (2007) Propagação in vitro de orquídeas brasileiras em meio de cultura simplificado. Revista Brasileira de Agrociência 13: 267-269.

Vacin EF \& Went FW (1949) Some pH changes in nutrient solutions. Botanical Gazette 110: 605-617.

Vasudevan R \& van Staden J (2010) In vitro asymbiotic seed germination and seedling growth of Ansellia africana Lindl. Scientia Horticulturae 123: 496-504.

Wochok ZS (1981) The role of tissue culture in preserving threatened and endangered plant species. Biological Conservation 20: 83-89.

Zeng SJ, Chen ZL, Wu KJ, Zhang JX, Bai CK, Silova JAT \& Duan J (2011) Asymbiotic seed germination, induction of calli and protocorm-like bodies and in vitro seedling development of the rare and endangered Nothodoritis zhejiangensis, a Chinese orchid. HortScience 46: 460-465. 